Biogeosciences, 10, 4211-4225, 2013

www.biogeosciences.net/10/4211/2013/

doi:10.5194/bg-10-4211-2013

(C) Author(s) 2013. CC Attribution 3.0 License.

\title{
Numerical modelling of methyl iodide in the eastern tropical Atlantic
}

\author{
I. Stemmler ${ }^{1}$, M. Rothe ${ }^{1, *}$, I. Hense ${ }^{1}$, and H. Hepach ${ }^{2}$ \\ ${ }^{1}$ Institute for Hydrobiology and Fisheries Science, CEN, University of Hamburg, Hamburg, Germany \\ ${ }^{2}$ GEOMAR Helmholtz Centre for Ocean Research Kiel, Kiel, Germany \\ * now at: Leibniz Institute of Freshwater Ecology and Inland Fisheries, Berlin, Germany
}

Correspondence to: I. Stemmler (irene.stemmler@zmaw.de)

Received: 19 December 2012 - Published in Biogeosciences Discuss.: 24 January 2013

Revised: 21 May 2013 - Accepted: 23 May 2013 - Published: 25 June 2013

\begin{abstract}
Methyl iodide $\left(\mathrm{CH}_{3} \mathrm{I}\right)$ is a volatile organic halogen compound that contributes significantly to the transport of iodine from the ocean to the atmosphere, where it plays an important role in tropospheric chemistry. $\mathrm{CH}_{3} \mathrm{I}$ is naturally produced and occurs in the global ocean. The processes involved in the formation of $\mathrm{CH}_{3} \mathrm{I}$, however, are not fully understood. In fact, there is an ongoing debate whether production by phytoplankton or photochemical degradation of organic matter is the main source term. Here, both the biological and photochemical production mechanisms are considered in a biogeochemical module that is coupled to a one-dimensional water column model for the eastern tropical Atlantic. The model is able to reproduce observed subsurface maxima of $\mathrm{CH}_{3} \mathrm{I}$ concentrations. But, the dominating source process cannot be clearly identified as subsurface maxima can occur due to both direct biological and photochemical production. However, good agreement between the observed and simulated difference between surface and subsurface methyl iodide concentrations is achieved only when direct biological production is taken into account. Production rates for the biological $\mathrm{CH}_{3}$ I source that were derived from published laboratory studies are shown to be inappropriate for explaining $\mathrm{CH}_{3} \mathrm{I}$ concentrations in the eastern tropical Atlantic.
\end{abstract}

\section{Introduction}

Methyl iodide $\left(\mathrm{CH}_{3} \mathrm{I}\right)$ is one main carrier of iodine from the ocean to the atmosphere (Lovelock et al., 1973). Upon volatilization to the atmosphere it rapidly (within five days) transforms into reactive iodine species and impacts the tropospheric chemistry, such as the oxidative capacity and ozone depletion (e.g. Chameides and Davis, 1980; Solomon et al., 1994; Vogt et al., 1999). In coastal regions macro-algae were identified as significant methyl iodide sources (e.g. Manley and Dastoor, 1988; Nightingale et al., 1995; Carpenter, 2003), but they are not the major producers on the global scale due to their restricted distribution and small production rates (e.g. Giese et al., 1999; Wang et al., 2009). In the open ocean, $\mathrm{CH}_{3} \mathrm{I}$ sources are unclear, and uncertainties remain with regard to origin of the source as well as production rates. Most studies suggested either a biological or a photochemical production pathway. Laboratory experiments in which filtered sea water was irradiated show photochemical production of $\mathrm{CH}_{3} \mathrm{I}$ in absence of living phytoplankton cells that could account for at least $50 \%$ of observed $\mathrm{CH}_{3} \mathrm{I}$ emissions from the tropical Atlantic (Richter and Wallace, 2004). In addition, there is direct evidence for the biological production pathway (e.g. Moore and Tokarczyk, 1993; Manley and De La Cuesta, 1997); in particular the picocyanobacteria Prochlorococcus produce $\mathrm{CH}_{3} \mathrm{I}$ (Brownell et al., 2010). The $\mathrm{CH}_{3} \mathrm{I}$ production rates that have been independently derived for the same species by different research groups, however, are several orders of magnitude apart (Smythe-Wright et al., 2006; Brownell et al., 2010). While it was unclear whether differences in experimental setups in these laboratory studies can explain the discrepancies, a recent work provides an alternative explanation. Apparently, the production of methyl iodide is related to the health of these unicellular organisms; enhanced production rates by an order of magnitude have been recorded under 
stress conditions (Hughes et al., 2011). So far, oceanic $\mathrm{CH}_{3} \mathrm{I}$ production has been quantified only in few modelling studies. Based on a very limited data set, best agreement between observations and model results from a global atmospheric chemistry-transport model (Bell et al., 2002) has been obtained when considering only a photochemical source instead of biological production. However, it has been criticized that the simulated photochemical source is too strong and the parametrization possibly too crude to represent $\mathrm{CH}_{3} \mathrm{I}$ production (Moore, 2006). Since then more data on $\mathrm{CH}_{3} \mathrm{I}$ in the environment have been collected and new insights in $\mathrm{CH}_{3} \mathrm{I}$ production published. The existing uncertainties show the need to readdress the origin of oceanic $\mathrm{CH}_{3} \mathrm{I}$ applying recent process understandings. Here, we present results from model experiments in which both the biological and photochemical production mechanisms are considered. We compare simulated concentrations of $\mathrm{CH}_{3} \mathrm{I}$ with observations in sea water in order to assess distribution and strength of natural $\mathrm{CH}_{3} \mathrm{I}$ sources in the ocean. A methyl iodide source and sink module is developed and coupled to a biogeochemical model as well as to the water column model GOTM. This model system is applied to simulate $\mathrm{CH}_{3} \mathrm{I}$ concentrations in the eastern tropical Atlantic. By comparing observed and simulated vertical profiles of methyl iodide, we aim at identifying possible sources and sinks. Additionally, we want to quantify the air-sea flux of $\mathrm{CH}_{3} \mathrm{I}$ and determine the sensitivity of this exchange process towards different parameterization for $\mathrm{CH}_{3} \mathrm{I}$ production.

\section{Material and methods}

\subsection{Model description}

The physical model used is the "General Ocean Turbulence Model" (GOTM, Umlauf et al., 2005). GOTM is a one-dimensional water column model that mimics a number of hydrodynamic and thermodynamic processes related to vertical mixing in natural waters. It derives solutions for the one-dimensional versions of the transport equations of momentum, salt, and heat, and includes well-tested turbulence models. These models span the range from simple prescribed expressions for the turbulent diffusivities up to complex Reynolds-stress models with several differential transport equations to solve. We use a so-called two-equation model in which the turbulent kinetic energy (TKE) and the length scale of turbulence (l) are calculated from differential transport equations. They are described by a $k-\varepsilon$-type equation for TKE and a dynamic dissipation rate model for 1 (details in Umlauf et al., 2005). In line with Hense and Quack (2009) a minimum value of $10^{-5} \mathrm{~m}^{2} \mathrm{~s}^{-2}$ for TKE is prescribed to parameterize the effects of double diffusion in the Cape Verde region.

Phytoplankton dynamics are simulated using a single column implementation of HAMOCC5.2 (Six and Maier-
Reimer, 1996; Wetzel et al., 2006; Ilyina et al., 2013). HAMOCC is a marine carbon cycle model that includes a NPZD-type ecosystem model. The latter resolves exchange processes between several compartments: phytoplankton, zooplankton, sinking particulate organic carbon, a semilabile dissolved organic carbon, and nutrients (iron, nitrate, and phosphate).

\subsubsection{Methyl iodide modelling}

The methyl iodide module considers several source and sink processes of $\mathrm{CH}_{3} \mathrm{I}$ and has been implemented into the biogeochemical module HAMOCC. The methyl iodide concentration $\left(c\left[\mathrm{mmol} \mathrm{m}^{-3}\right]\right)$ evolves over time following production $(P)$, degradation $(S)$, air-sea exchange $(F)$, as well as turbulent vertical diffusion ( $A_{v}$-diffusion coefficient).

$$
\frac{\mathrm{d} c}{\mathrm{~d} t}=P-S+F_{\text {air-sea }}+\frac{\partial}{\partial z}\left(A_{v} \frac{\partial c}{\partial z}\right)
$$

Two production mechanisms are implemented: photochemical production by radical recombination between methyl groups and iodine atoms $\left(P_{\text {photo }}\right)$ and direct biological production by phytoplankton $\left(P_{\mathrm{PP}}\right)$. Photochemical production is parameterized using radiation (RAD) and a dissolved organic carbon concentration (DOC) (in $\mathrm{kmolPm}^{-3}$ as phosphorus is the model's internal "currency" of organic material. The model assumes a constant Redfield ratio of $1: 106$ for $\mathrm{P}: \mathrm{C}$ in DOC). Here, (RAD) triggers the formation of methyl groups in the presence of organic matter and the production of iodine atoms from the photolysis of organic iodide. The photochemical production of methyl iodide concentration over time is then parameterized as follows:

$P_{\text {photo }}=k_{\text {photo }} \cdot \mathrm{RAD} \cdot \mathrm{DOC}$,

where $k_{\text {photo }}$ is the photochemical production rate in $\mathrm{m}^{2} \mathrm{mmolCH}_{3} \mathrm{I}(\mathrm{kmolP})^{-1} \mathrm{~W}^{-1} \mathrm{~s}^{-1}$. RAD represents either UV light as parameterized in the photolysis (see below) or the photosynthetically active radiation (PAR) given by HAMOCC. Both are implemented as there is no experimental evidence that $\mathrm{CH}_{3} \mathrm{I}$ production occurs preferentially under UV light (Richter and Wallace, 2004). The term DOC gathers a large variety of different substances with very different properties of different origin as "dissolved" is an operational definition for material passing a $0.45 \mu \mathrm{m}$ filter. DOC can be directly produced in the ocean or originate from terrigenous decomposed plant material. Marine processes that form DOC include mainly extracellular release by phytoplankton, grazer mediated release and excretion, release via cell lysis, solubilization of particles, and bacterial transformation and release (Carlson, 2002). Relevant for $\mathrm{CH}_{3} \mathrm{I}$ production are the DOC's photochemical properties, i.e. its ability to release methyl radicals. Photochemical transformation thereby can change the bioavailability of DOC in both directions - i.e. can make it more recalcitrant or more bioavailable 
(Sulzberger and Durisch-Kaiser, 2009). To cover DOC pools of different lability two types of experiments with photochemical production of $\mathrm{CH}_{3} \mathrm{I}$ are performed. In one group of experiments the semi-labile DOC (SLDOC) pool of pure marine origin as provided by HAMOCC is used as a source for methyl groups. In the second group of experiments the DOC concentration is set to a constant value of $40 \mu \mathrm{molC} \mathrm{kg}{ }^{-1}$. This mimics an unlimited supply of DOC and enables us to assess whether the spatio-temporal behaviour of DOC affects $\mathrm{CH}_{3} \mathrm{I}$ production in the model. In the following this production pathway is referred to as photochemical production from refractory DOC (RDOC) as a very long life time of DOC would lead to almost uniform distribution in the ocean.

Direct biological production of $\mathrm{CH}_{3} \mathrm{I}$ by phytoplankton is parameterized as follows:

$P_{\mathrm{PP}}=k_{\mathrm{PP}} \cdot \mu(T, N, \mathrm{PAR}) \cdot \mathrm{PHY}$.

Here, PHY is the phytoplankton concentration in $\mathrm{kmolPm}^{-3}$ and $\mu(T, N, \mathrm{PAR})$ is the actual growth rate of phytoplankton. The coefficient that specifies how much methyl iodide is produced during primary production is called $k_{\mathrm{PP}}$ ratio $\left[\mathrm{mmolCH}_{3} \mathrm{I}\left(\mathrm{kmolP}^{-1}\right]\right.$. This proportionality coefficient has been derived from two different laboratory studies: Moore et al. (1996) conducted incubation experiments with the phytoplankton species Nitzschia sp. and Smythe-Wright et al. (2006) incubated the cyanobacteria species Prochlorococcus marinus. Both measured an increase of methyl iodide concentration during the exponential growth phase of phytoplankton. In order to determine this coefficient, first the maximum specific growth rates $\omega$ in $\left(\mathrm{d}^{-1}\right)$ of these two species have been extracted from the exponential growth phase. The observed change in cell abundance is a function of the actual (net) growth rate $\mu$. Since the maximum specific growth rate is required (see also Hense and Quack, 2009), a respiration rate of $1 \% \mathrm{~d}^{-1}$ is assumed.

Solving the ordinary differential equation for the experiment explained above,

$\frac{\mathrm{dPHY}}{\mathrm{d} t}=\mu \cdot \mathrm{PHY}$

and rearranging it to solve for $\mu$

$\mu=\frac{\ln \left(\frac{\mathrm{PHY}}{\mathrm{PHY}_{0}}\right)}{\Delta t}$

the phytoplankton production within $\Delta t$ is

Phytoplankton production $=\omega \cdot \mathrm{PHY}_{0} \cdot e^{\omega \cdot \Delta t}$,

with $\mathrm{PHY}_{0}$ and PHY accounting for the cell counts at the beginning and the end of the exponential growth phase; $\Delta t$ is the time interval and $\omega=\mu+0.01 \mathrm{~d}^{-1}$. Then the corresponding change of methyl iodide concentration $\Delta \mathrm{CH}_{3} \mathrm{I}$ in the same time interval $\Delta t$ is determined in order to calculate the ratio between methyl iodide production and primary production $k_{\mathrm{PP}}$ :

$$
\begin{aligned}
k_{\mathrm{PP}} & =\frac{\text { Methyl iodide production }}{\text { Phytoplankton production }} \\
& =\frac{\Delta \mathrm{CH}_{3} \mathrm{I}}{\Delta t \cdot \omega \cdot \mathrm{PHY}_{0} \cdot e^{\omega \cdot \Delta t} .}
\end{aligned}
$$

The resulting values for $k_{\mathrm{PP}}$ are 0.12 $\mathrm{mmolCH}_{3} \mathrm{I}(\mathrm{kmolP})^{-1}$ for Nitzschia sp. and $1488.00 \mathrm{mmolCH}_{3} \mathrm{I}(\mathrm{kmolP})^{-1}$ for Prochlorococcus marinus, using typical cellular carbon contents for both species (Partensky et al. (1999): $50 \times 10^{-15} \mathrm{~g} \mathrm{C}$ cell $^{-1}$ for Prochlorococcus marinus; $147 \times 10^{-12} \mathrm{~g} \mathrm{C}$ cell $^{-1}$ for Nitzschia sp.; see also Hense and Quack, 2009) as well as the conversion factors from weight to molar units and the molar Redfield ratio $(\mathrm{P}: \mathrm{C}=1: 106)$. Under stress conditions the ratio between primary production and production of organic halogens significantly increases (Hughes et al., 2011). As picocyanobacteria are very abundant in the oligotrophic ocean (Partensky et al., 1999), and a large fraction of cells is in an unhealthy state (Agusti, 2004), we take nutrient limitation $N_{\text {lim }}$ as a simple proxy for picocyanobacteria and for stress conditions to identify possible unhealthy cell states of phytoplankton:

$N_{\lim }=\frac{N}{N+k_{\mathrm{N}}}$,

where $N$ is the nutrient concentration and $k_{\mathrm{N}}$ the halfsaturation constant for nutrients. When enhanced production under nutrient limitation is simulated, $k_{\mathrm{PP}}$ varies between a minimum value under nutrient-rich conditions $\left(N_{\text {lim }}=0.999\right.$ ) and a maximum value under extremely oligotrophic conditions $\left(N_{\text {lim }}=0.001\right)$ :

$k_{\mathrm{PP}}=a \cdot \exp \left(-b N_{\mathrm{lim}}\right)$.

with

$b=\frac{\ln \left(\frac{k_{\mathrm{PP}_{\min }}}{k_{\mathrm{P} \max }}\right)}{0.001-0.999}$

and

$a=\frac{k_{\mathrm{PP}_{\max }}}{\exp (-b \cdot 0.001)}$.

This non-linear approach was chosen to test the sensitivity versus minimum and maximum values of $k_{\mathrm{PP}}$ which can span several orders of magnitude. A linear approach here would over-represent the high values.

$\mathrm{CH}_{3} \mathrm{I}$ degradation includes nucleophilic substitution with chloride $S_{\mathrm{Cl}}$, hydrolysis $S_{\text {hyd }}$, and photolysis $S_{\text {phot }}$. Chloride substitution and hydrolysis are implemented as first-order processes with temperature-dependent decay rates:

$S_{\mathrm{Cl}}=k_{\mathrm{Cl}}(T) \cdot c_{\mathrm{Cl}} \cdot c$ 
and

$S_{\text {hyd }}=k_{\text {hyd }}(T) \cdot c$.

For chloride substitution a constant chloride ion sea water concentration of $c_{\mathrm{Cl}}=0.54 \mathrm{molL}^{-1}$ was adopted, which is a typical value when assuming a mean sea water salinity $S=35$ and a chloride ion proportion of $55 \%$ (following the law of constant proportions after Dittmar, 1884). The reaction rate was derived by Elliott and Rowland (1993):

$k_{\mathrm{cl}}=A \cdot \exp \left(-\frac{B}{T}\right)$,

with $A=7.78 \times 10^{13} \mathrm{Lmol}^{-1} \mathrm{~s}^{-1}$, and $B=13518 \mathrm{~K} ; T$ is temperature in $K$. The reaction rates for hydrolysis were determined by Elliott and Rowland (1995) with $A=1.7 \times 10^{12} \mathrm{~s}^{-1}$, and $B=13300 \mathrm{~K}$. Photolysis is implemented as proportional to UV attenuation $\left(a_{\mathrm{uv}}=0.33 \mathrm{~m}^{-1}\right)$, and irradiance (I) relative to its annual mean $I_{\text {ref }}$ :

$S_{\text {photo }}=k_{\mathrm{uv}} \cdot \frac{I}{I_{\text {ref }}} \exp \left(-a_{\mathrm{uv}} z\right)$.

The rate constant $k_{\mathrm{uv}}\left[\mathrm{s}^{-1}\right]$ is estimated from atmospheric degradation rates (Rattigan et al., 1997) because reaction kinetics of methyl iodide photolysis in sea water are unknown. In particular, the e-folding time $\left(k_{\mathrm{uv}}\right)^{-1}$ is set to 10 days assuming photo-dissociation of methyl iodide in water occurs at $50 \%$ of the respective atmospheric rate. This approach was adopted from Carpenter and Liss (2000), who estimate kinetics of bromoform photolysis in water in a similar manner.

Gas exchange is calculated from the two-film model assuming methyl iodide gas exchange is controlled by the water side due to its low water solubility. Hence, the flux is calculated from a time-invariant field of atmospheric concentrations, solubility (Henry's law constant), bulk surface water concentrations, the Schmidt number, and a transfer velocity.

$F_{\text {air-sea }}=k_{\mathrm{w}} \cdot\left(c-\frac{c_{\mathrm{a}}}{H}\right)$

The transfer velocity $k_{\mathrm{W}}$ depends on wind speed and is calculated according to Nightingale et al. (2000):

$k_{\mathrm{w}}=\left(\frac{\mathrm{Sc}_{\mathrm{CH}_{3} \mathrm{I}}}{600}\right)^{-\frac{1}{2}} \cdot\left(6.16 \times 10^{-7} \mathrm{sm}^{-1} \cdot u_{10}{ }^{2}+9.25 \times 10^{-7} u_{10}\right)$,

with $u_{10}$ denoting the wind speed at $10 \mathrm{~m}$ above the sea surface, and $\mathrm{Sc}_{\mathrm{CH}_{3} I}$ the Schmidt number for methyl iodide. The Schmidt number has been estimated from that of methyl bromide and the ratio of their molar volumes, as it has been done previously (e.g. Moore and Groszko, 1999):

$\mathrm{Sc}_{\mathrm{CH}_{3} \mathrm{I}}=\left(\frac{62.9}{52.9}\right)^{0.6} \cdot\left(2004-93.5^{\circ} \mathrm{C}^{-1} \cdot T+1.39^{\circ} \mathrm{C}^{-2} \cdot T^{2}\right)$,

with $T$ temperature in ${ }^{\circ} \mathrm{C}\left(5-30^{\circ} \mathrm{C}\right)$. The temperature dependence of the solubility was determined by Moore et al. (1995):

$H=\exp \left(13.32-\frac{4338 \mathrm{~K}}{T}\right)$

with $T$ temperature in $\mathrm{K}$.
Table 1. Parameter setup of the NPZD model, default HAMOCC values (Ilyina et al., 2013) and new values after tuning to fit observations close to Cape Verde.

\begin{tabular}{lcc}
\hline Parameter & Default value & New value \\
\hline $\begin{array}{l}\text { Phytoplankton mortality rate } \\
\text { (water column) }\left[\mathrm{d}^{-1} \text { ] }\right.\end{array}$ & 0.1 & 0.3 \\
$\begin{array}{l}\text { Maximum grazing rate } \\
{\left[\mathrm{d}^{-1} \text { ] }\right.}\end{array}$ & 1.0 & 0.7 \\
$\begin{array}{l}\text { Initial slope of the P-I curve } \\
\text { Half saturation constant for } \\
\text { nutrient uptake }\left[\mathrm{kmolPm}^{-3}\right]\end{array}$ & 0.02 & 0.025 \\
\hline
\end{tabular}

\subsection{Model setup}

In order to receive a realistic simulation for a given oceanic region the model has to be configured for the conditions in a specific region. In this study, GOTM is configured for the Cape Verde region in the eastern tropical North Atlantic Ocean (latitude: $16^{\circ} \mathrm{N}$, longitude: $24^{\circ} \mathrm{W}$ ), like in Hense and Quack (2009). The physical model covers the upper $700 \mathrm{~m}$ of the ocean and has a vertical resolution of $2 \mathrm{~m}$. The lower boundary of the model is set at this depth because here the nutrient maximum occurs and all diffusive fluxes vanish. A two-equation $\mathrm{k}-\varepsilon$ model with an algebraic second momentum closure is used, which is similar to Weber et al. (2007). For numerical integration a so-called quasi-implicit numerical scheme for the turbulence model with a time step of $1 \mathrm{~h}$ is used. The coupled physical-biogeochemical model is forced by climatological monthly mean data of $2 \mathrm{~m}$ atmospheric air temperature, air pressure, dew point temperature, $10 \mathrm{~m}$ zonal and meridional wind velocities, cloud cover, and precipitation based on the $40 \mathrm{yr}$ ECMWF Re-analysis (ERA40) data (Uppala et al., 2005). The variables for water temperature and salinity are initialized with climatological profiles from the World Ocean Atlas (WOA01) (Conkright et al., 2002). The NPZD model parameters were tuned to closer match conditions at Cape Verde (see Appendix and Table 1).

For the calculation of the air-sea gas exchange a constant methyl iodide air concentration of $6.23 \times 10^{-8} \mathrm{mmolm}^{-3}$ is assumed which corresponds to $1.5 \mathrm{ppt}$ at $20^{\circ} \mathrm{C}$ and is the mean of observed base-level air concentrations of methyl iodide at Cape Verde during May and June 2007 (O'Brien et al., 2009). To account for lateral entry of higher-saline water, which is characteristic for the Cape Verde region, salinity and temperature values are restored towards climatological monthly means of WOCE (World Ocean Circulation Experiment; Global Data Resource) with a five day time scale, except for the upper $20 \mathrm{~m}$ of the water column. The dissolved inorganic nitrogen concentration is restored at the nutrient maximum to the observed value of $35.7 \mathrm{mmol} \mathrm{Nm}^{-3}$, and dissolved inorganic phosphate to an observed value of $2.23 \mathrm{mmol} \mathrm{Pm}^{-3}$ with a time scale of one hour. 


\subsection{Observations}

To evaluate the simulated $\mathrm{CH}_{3}$ I concentrations, model results are compared to observations from a ship cruise in the tropical northeast Atlantic close to Cape Verde - i.e. the Poseidon cruise P399/2 in April-June 2010 (Bange, 2011) (see Appendix A). Methyl iodide profiles have been obtained from three stations, one of which is located in an upwelling region and is therefore not further considered (since a 1-D water column model cannot simulate upwelling conditions). The other two stations are located at $17.6^{\circ} \mathrm{N} 24.3^{\circ} \mathrm{W}$ (St. $307-$ in the following called CVOO, which stands for Cape Verde Ocean Observatory), and $18^{\circ} \mathrm{N} 21^{\circ} \mathrm{W}$ (St. 308).

Dissolved $\mathrm{CH}_{3} \mathrm{I}$ was measured in sea water sampled in $500 \mathrm{~mL}$ amber glass bottles from 10 different depths at CVOO and station 308 . These samples were taken from $10 \mathrm{~L}$ Niskin bottles that were installed on a 12-bottle rosette with a CTD (conductivity temperature depth). A purge and trap system attached to a gas chromatograph with mass spectrometer (GC-MS) and detection in single ion mode were used to analyse the samples. Eighty millilitres of the sampled water was heated up to $70^{\circ} \mathrm{C}$ while being purged with a stream of helium at $30 \mathrm{mLmin}^{-1}$ in a glass chamber. Volatilized trace gases were trapped on glass beads at $-100^{\circ} \mathrm{C}$ and were desorbed onto a deactivated capillary in liquid nitrogen as second trap at $100^{\circ} \mathrm{C}$ after one hour of purging. The trace gases were injected into the GC-MS after three minutes. Volumetrically prepared standards in methanol were used for quantification. Precision of the measurements is estimated to be $16 \%$, determined from duplicates with a detection limit of $0.05 \mathrm{pmolL}^{-1}$ for $\mathrm{CH}_{3} \mathrm{I}$. Besides methyl iodide concentrations, phytoplankton pigments, temperature, and salinity profiles are available for the three stations. Phytoplankton pigments, i.e. total chlorophyll $a$ concentrations, were converted into phytoplankton biomass by using a depthdependent $C: C h l$ ratio and assuming a $P: C$ ratio of $1: 106$. The $\mathrm{C}: \mathrm{Chl}$ ratio was calculated as described in Hense and Beckmann (2008) using modelled radiation profiles as irradiation was not measured. Calculated surface $\mathrm{C}: \mathrm{Chl}$ ratios are much higher $\left(>100 \mathrm{gg}^{-1}\right)$ than subsurface (minimum $25 \mathrm{gg}^{-1}$ ) ratios (not shown).

\subsection{Model experiments}

GOTM is run in several experiments including different combinations of the $\mathrm{CH}_{3} \mathrm{I}$ production processes (listed in Table 2). In the experiments E1 and E2 only direct production via phytoplankton growth is implemented and the production rates derived from laboratory studies by Moore et al. (1996) (E1) and Smythe-Wright et al. (2006) (E2) are tested. In experiment E3 the production rates by Moore et al. (1996) and Smythe-Wright et al. (2006) are used as the lower $\left(k_{\mathrm{PP}_{\min }}\right)$ and upper $\left(k_{\mathrm{PP}_{\max }}\right)$ boundaries of the variable biological production rate that mimics production by phytoplankton with consideration of stress. As the production rates for the pho-
Table 2. $\mathrm{CH}_{3} \mathrm{I}$ model parameter configurations of the different experiments. The unit of $k_{\mathrm{PP}}$ is $\left[\mathrm{mmolCH}_{3} \mathrm{I}(\mathrm{kmolP})^{-1}\right]$, the one of $k_{\text {photo }}$ is $\left[\mathrm{m}^{2} \mathrm{mmolCH}_{3} \mathrm{I}(\mathrm{kmolP})^{-1} \mathrm{~W}^{-1} \mathrm{~s}^{-1}\right]$.

\begin{tabular}{lcccc}
\hline $\begin{array}{l}\text { Experiment } \\
\text { ID }\end{array}$ & $k_{\mathrm{PP}_{\min }}$ & $k_{\mathrm{PP}_{\max }}$ & $\begin{array}{c}k_{\text {photo }} \\
(\mathrm{SLDOC})\end{array}$ & $\begin{array}{c}k_{\text {photo }} \\
(\mathrm{RDOC})\end{array}$ \\
\hline E1 & 0.12 & - & - & - \\
E2 & 1488.00 & - & - & - \\
E3 & 0.12 & 1488.00 & - & - \\
Opt1 & 56.00 & - & - & - \\
Opt2 & - & - & $1.31 \times 10^{-6}$ & - \\
Opt3 & - & - & - & $3.91 \times 10^{-7}$ \\
Opt4 & 0.14 & 1204.80 & - & - \\
Opt123 & 0.05 & - & $7.80 \times 10^{-7}$ & $1.26 \times 10^{-7}$ \\
\hline
\end{tabular}

tochemical production pathways (from SLDOC or RDOC) are unknown, they are derived from a parameter optimization. Thereby the parameter (set) that leads to the minimum root mean square deviation (RMSD),

$$
\begin{aligned}
\text { RMSD }=0.5 & \sqrt{\frac{1}{N_{\text {depth }}} \sum_{\text {depth }}\left(m_{\text {depth }}-o_{\text {depth }}\right)^{2}} \\
& +0.5 \sqrt{(\max (m)-\max (o))^{2}}
\end{aligned}
$$

between modelled $(m)$ and observed $(o)$ (see Sect. 2.3) profiles and maxima is found using a gradient descent search. The step length, i.e. the incremental parameter change, is set to $10 \%$ of the most successful parameter value of the previous iteration. Optimizing for both the overall RMSD and the deviation from the maximum ensures that when a subsurface maximum is simulated it will be of similar strength as in the observations, even when predicted at a different depth. Assuming that differences between CVOO and St. 308 are minor, no individual optimization for St. 308 was performed. The experiments Opt1-Opt4 include only one source process and the production rates are chosen by a parameter optimization. In the following, 1 denotes "normal" (not stressed) production by phytoplankton, 2 photochemical production through semi-labile DOC (SLDOC) degradation, 3 photochemical production through refractory DOC (RDOC) degradation, and 4 biological production with a variable production rate (i.e. with consideration of stress), where the lower and upper bounds are optimized. In the experiments Opt 2 and Opt $3, \mathrm{CH}_{3} \mathrm{I}$ production mechanisms through both UV and PAR were tested. In the experiment Opt123, three production processes are considered (i.e. biological and photochemical production from semi-labile and refractory DOC), and the respective rates are derived from a parameter optimization with three simultaneously varying parameters. 


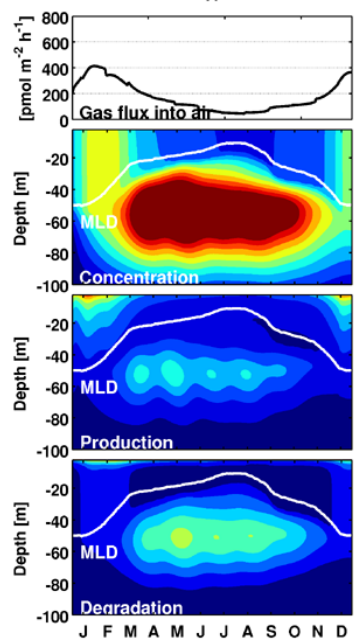

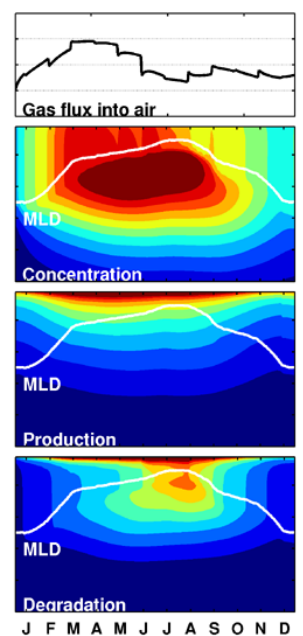

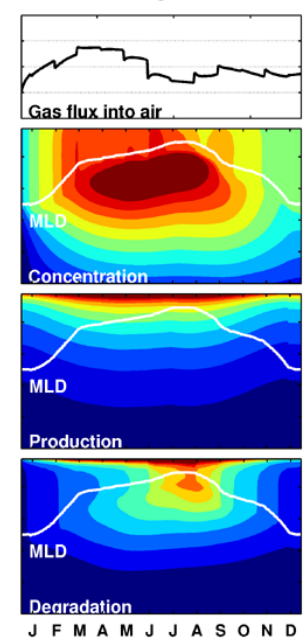

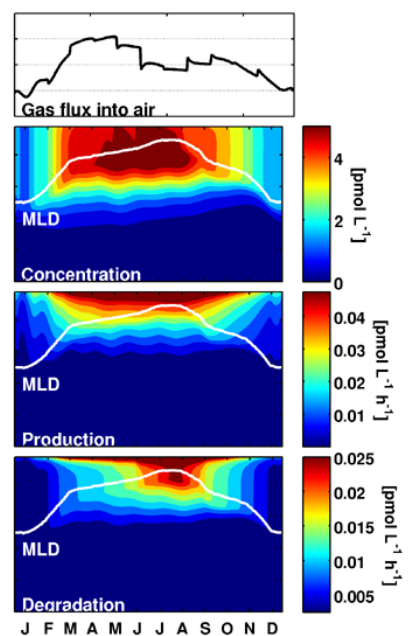

Fig. 1. Methyl iodide concentrations $\left[\mathrm{pmolL}^{-1}\right]$, production $\left[\mathrm{pmolL}^{-1} \mathrm{~h}^{-1}\right]$, degradation $\left[\mathrm{pmolL}^{-1} \mathrm{~h}^{-1}\right]$, and gas exchange [pmol m${ }^{-2} \mathrm{~h}^{-1}$ ] for the experiments Opt1 (column A), Opt2 (column B), Opt3 (column C), and Opt4 (column D).

\section{Results}

\subsection{Seasonal cycle of $\mathrm{CH}_{3} \mathrm{I}$ concentrations}

In the experiments that include only biological production of $\mathrm{CH}_{3} \mathrm{I}$ (Opt1, E1, E2), maximum production takes place between 50 and $80 \mathrm{~m}$ depth, i.e. where phytoplankton growth is largest (Fig. 1a). Consequently, a strong $\mathrm{CH}_{3} \mathrm{I}$ subsurface maximum builds up over the year, with highest concentrations in the summer season (May-September). In Opt2 and Opt3, photochemical production was modelled using either PAR or UV. Of these experiments only those that use PAR show a subsurface $\mathrm{CH}_{3} \mathrm{I}$ maximum (not shown). Location and cause of these maxima resulting from photochemical production are different from the experiments with biological production. Irrespective of the lability of the DOC pool considered, maximum $\mathrm{CH}_{3} \mathrm{I}$ production occurs in the sunlit surface layers (Fig. 1c, d). The production is stronger in summer than in winter months, following the seasonal cycle of insolation. During times of deep mixing, i.e. in winter months, the $\mathrm{CH}_{3} \mathrm{I}$ concentration is homogenous over the upper $50 \mathrm{~m}$. When the mixed layer shallows, a pronounced subsurface maximum evolves, which is first situated at approximately $50 \mathrm{~m}$ depth, but later follows the mixed layer shallowing up to approximately $30 \mathrm{~m}$ depth. In the uppermost model levels the dominant sink processes for $\mathrm{CH}_{3} \mathrm{I}$ are UV decay and gas exchange with the atmosphere. The subsurface maximum is not a result of a particularly strong local production (production always exceeds decay) but is caused by the stratification that shields the freshly produced $\mathrm{CH}_{3} \mathrm{I}$ from gas exchange. When photochemical production is parameterized using light that is efficiently absorbed in the surface layers (i.e. UV light identical to the parameterization of photolysis) $\mathrm{CH}_{3} \mathrm{I}$ production is restricted to the upper model levels and never takes place below the mixed layer. This inhibits the evolution of a subsurface maximum, and concentration maxima are always located in the mixed layer (not shown). Since subsurface maxima are observed, photochemical production by UV light seems unrealistic.

The experiments Opt 2 and Opt 3 show only minor differences, despite the different DOC pools considered as sources for available methyl groups. This is because the semi-labile DOC in HAMOCC shows a surface maximum throughout the year. Hence, the vertical distribution of $\mathrm{CH}_{3} \mathrm{I}$ production in both experiments is limited by light absorption leading to similar seasonal patterns.

In Opt4, when biological production is simulated and calculated from different production rates in oligotrophic water and the residual water column, the distribution of $\mathrm{CH}_{3} \mathrm{I}$ differs very much from that of "normal" biological production in e.g. Opt1 (Fig. 1d). Concentration maxima occur from May to September and stretch within the upper $40 \mathrm{~m}$ of the water column. Production is highest at the surface because nutrient scarcity (caused by strong stratification of the water) leads to a high $\mathrm{CH}_{3} \mathrm{I}$ production: PP ratio $k_{\mathrm{PP}}$ (Fig. 2). At the surface $k_{\mathrm{PP}}$ is $4-6$ times higher than in Opt 1 and is more than 100 times lower than in Opt1 subsurface where maximum primary production occurs (Fig. 2a). The distribution of $\mathrm{CH}_{3} \mathrm{I}$ in Opt123 is almost identical to Opt 2 and Opt3 because $k_{\mathrm{PP}}$ is even smaller than in the experiment with the low biological production rate derived from laboratory experiments (E1, Table 2).

\subsection{Evaluation of simulated $\mathrm{CH}_{3} \mathrm{I}$ concentrations}

In the experiments E1 and E2 - i.e. when considering only biological production using the rates derived from laboratory studies (Table 2) - different concentration distributions 

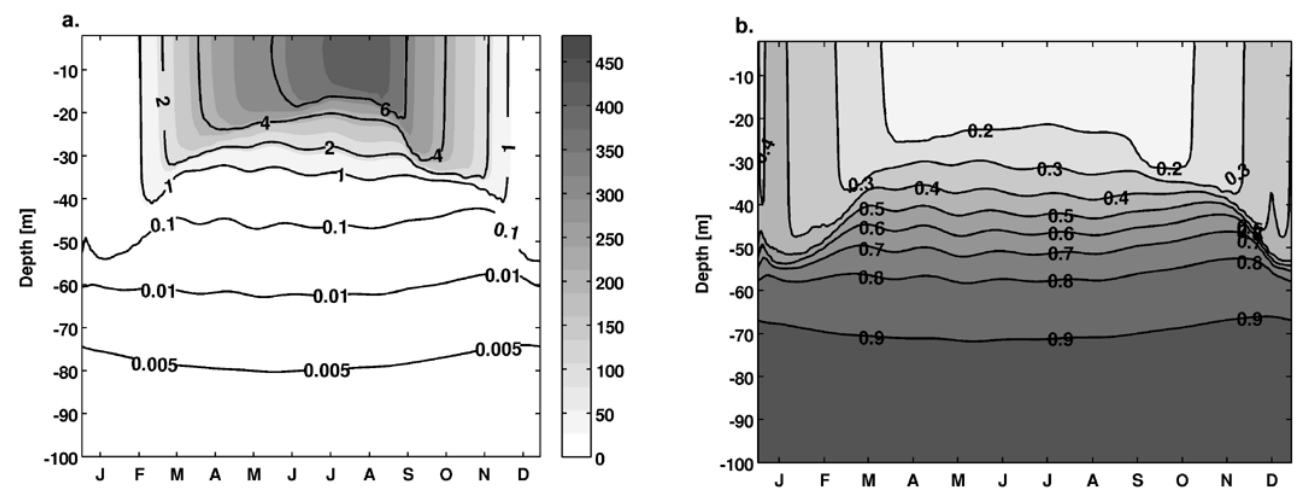

Fig. 2. Ratio between methyl iodide and primary production rate $k_{\mathrm{PP}}$ in $\mathrm{Opt} 4\left(\mathbf{a}\right.$, grey shaded area, $\left[\mathrm{mmol} \mathrm{CH}_{3} \mathrm{I}\left(\mathrm{kmolP}^{-1}\right]\right)$, its relation to $k_{\mathrm{PP}}$ in Opt1 (i.e. $\frac{k_{\mathrm{PP}} \mathrm{Opt4}}{k_{\mathrm{PP}} \text { Opt1 }}$ ) (a, contour lines), and the nutrient limitation factor $N_{\text {lim }}$ (b).

evolve resulting from the balance between production, degradation and gas exchange with the atmosphere. In both experiments $\mathrm{CH}_{3} \mathrm{I}$ production is tied to primary production, that has its maximum subsurface. Nevertheless, as a result of a low $k_{\mathrm{PP}}$, production and therefore surface concentration are much too low in E1. This leads to an undersaturation of the ocean and a net influx of $\mathrm{CH}_{3} \mathrm{I}$ from the atmosphere throughout the year. In contrast, in E2 a pronounced subsurface maximum of $\mathrm{CH}_{3} \mathrm{I}$ develops that is too high. The observed maximum and mean concentrations are $5.66,1.49 \mathrm{pmolL}^{-1}$ at CVOO; and 3.34, $0.66 \mathrm{pmolL}^{-1}$ at St. 308 (Table 3). The model in turn predicts for the respective month maximum and mean concentrations of $0.11,0.02 \mathrm{pmolL}^{-1}$ in $\mathrm{E} 1 ; 173.2$, $60.67 \mathrm{pmolL}^{-1}$ in $\mathrm{E} 2$ for CVOO; $0.14,0.004 \mathrm{pmolL}^{-1}$ in E1; and $187.65,70.43 \mathrm{pmolL}^{-1}$ in E2 for St. 308. Only the surface value of E1 matches the observations at St. 308 within a factor of 2. But, this apparent match is insignificant considering the large discrepancy (between observations and E1 model results) in subsurface concentrations. Thus, in both experiments unrealistic concentrations of $\mathrm{CH}_{3} \mathrm{I}$ occur. Mean and maximum values in the third experiment $\mathrm{E} 3$, which allows for a variable biological $\mathrm{CH}_{3} \mathrm{I}$ production rate using the parameters from laboratory studies as lower and upper bounds, match observed mean and maximum values much better (i.e. within a factor of 2) than the ones of E1 and E2. But, the vertical profile differs from the observed one: the strong production at the surface leads to concentrations that are much too high (100 times compared to CVOO, 6-fold compared to St. 308; see Table 3).

Next, the model runs with parameter optimization for "normal" biological production, photochemical production (from RDOC and SLDOC), biological production with a variable $k_{\mathrm{PP}}$, and combined biological and photochemical production were performed. For the experiment with mixed sources (Opt123) the optimization results in a very low biological production rate $k_{\mathrm{PP}}$ (Table 2 ), and consequently in a dominance of the photochemical production pathways.
Therefore, the methyl iodide concentration evolves similarly to Opt2 and Opt3 (Fig. 1b, c).

Results of the experiments using optimized parameter values compared to observations are depicted in a Taylor diagram (Fig. 3). This shows the RMSD (Eq. 20) normalized to the observed mean concentration at CVOO and St. 308 (Fig. 3), the standard deviation across the profile normalized to the profiles' mean concentration, and the correlation coefficient between modelled and observed profile. Of course, correlation and standard deviation are weak measures for the match between model and observations here due to the low data resolution. Nevertheless, they can give a hint on the similarity of the shapes of modelled and observed profiles. Unfortunately, the temporal evolution of $\mathrm{CH}_{3} \mathrm{I}$ concentration cannot be evaluated at all because there are no longterm $\mathrm{CH}_{3} \mathrm{I}$ data that would allow for assessing the seasonal cycle in the eastern tropical Atlantic. Observed methyl iodide concentrations show a subsurface maximum at around $40-50 \mathrm{~m}$ at both stations (Fig. 4). Due to the parameter optimization, all of the experiments simulate $\mathrm{CH}_{3} \mathrm{I}$ concentrations that are close to the observed maximum and mean values at CVOO, and match observed profiles much better than E1-3 (see Table 3). At CVOO the maximum concentration and concentrations below the maximum are well represented in almost all experiments, except Opt4 (Fig. 4). In the Taylor diagram, Opt2, Opt3, and Opt123 are clustered closely at approximately the same distance from the observations as their profiles are very much alike (Fig. 4). According to the Taylor diagram (Fig. 3a), Opt1 is closest to the observations as it is the only experiment that reproduces the observed vertical gradient with low surface and higher subsurface concentrations. This translates into a higher correlation coefficient and a lower RMSD. Surface concentrations of the experiments that are dominated by photochemical production (Opt2, Opt3, Opt123) are too high compared to observations (Fig. 4, Table 3). For Opt4, the optimization converged to values that are not very different from the values at E3 (Table 2) 
Table 3. Observed and modelled concentrations at the surface, concentration minima, and maxima [pmolL $\mathrm{L}^{-1}$ ]. Modelled values are means of the respective months at the depth of the observations.

\begin{tabular}{lcccccc}
\hline & \multicolumn{3}{c}{ Maximum } & \multicolumn{2}{c}{ Mean } & \multicolumn{2}{c}{ Surface } \\
Experiment ID & CVOO & St. 308 & CVOO & St. 308 & CVOO & St. 308 \\
\hline E1 & 0.11 & 0.14 & 0.02 & 0.004 & 0.11 & 0.14 \\
E2 & 173.20 & 187.65 & 60.67 & 70.43 & 28.64 & 38.16 \\
E3 & 6.24 & 5.67 & 1.23 & 1.57 & 6.24 & 5.55 \\
Opt1 & 6.52 & 7.08 & 2.30 & 2.68 & 1.18 & 1.57 \\
Opt2 & 5.60 & 5.04 & 2.00 & 2.31 & 4.66 & 4.65 \\
Opt3 & 5.36 & 4.98 & 2.14 & 2.46 & 4.52 & 4.37 \\
Opt4 & 5.34 & 4.94 & 1.08 & 1.39 & 5.34 & 4.83 \\
Opt123 & 5.07 & 4.62 & 1.89 & 2.18 & 4.24 & 4.19 \\
\hline Observation & 5.66 & 3.34 & 1.49 & 0.66 & 0.06 & 0.9 \\
\hline
\end{tabular}

a.
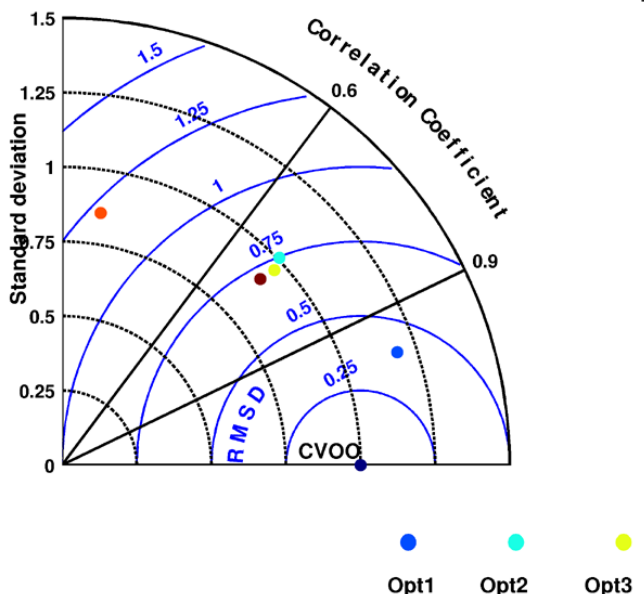

b.

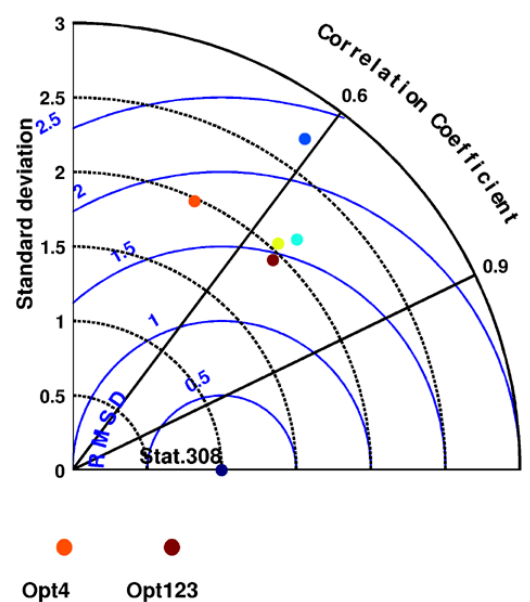

Fig. 3. Taylor diagrams for the different experiments showing the RMSD between modelled and observed profiles normalized with the observed mean concentration (blue circles), standard deviations of the individual profiles normalized with the one of the observations (black circles, ticks on the $\mathrm{y}$-axis), and the linear correlation coefficient between model results and observations (angle between $\mathrm{y}$ - and $\mathrm{x}$-axis). Note that all statistical parameters are derived from the vertical profiles, not from a time series. Observations are from CVOO (a) and St. 308 (b).

and the representation of methyl iodide in that model experiment also did not improve much over the ones in E3. Compared to CVOO, most simulated vertical profiles show a too shallow maximum, with too low values below and too high surface values. Observations at St. 308 are generally worse represented by this model setup than observations at CVOO. A further parameter optimization would bring simulated concentrations closer to observed ones, but would not bring any further insights into $\mathrm{CH}_{3} \mathrm{I}$ production. Also here (at St. 308) it is apparent that the experiment with $\mathrm{CH}_{3} \mathrm{I}$ production by phytoplankton (Opt1) is the only one that can reproduce the sharp subsurface gradient of the observations when all others show rather high surface concentrations compared to the subsurface maximum (Fig. 4, Table 3).

\subsection{Emissions}

In all experiments with optimized production rates the ocean acts as a source of $\mathrm{CH}_{3} \mathrm{I}$ to the atmosphere. Flux maxima for most experiments but Opt1 occur in spring (March-May, Fig. 5) due to high surface ocean concentrations during these times. In Opt1 highest emissions occur in winter (December, January, February), when both $\mathrm{CH}_{3} \mathrm{I}$ production at the surface (Fig. 1a) and wind speed (Fig. 5) are high. The fluxes are of similar order of magnitude for all experiments (maxima at approximately $\left.500 \mathrm{pmol} \mathrm{m}^{-2} \mathrm{~h}^{-1}\right)$. The primary driver of direction and annual cycle of gas exchange is the concentration of $\mathrm{CH}_{3} \mathrm{I}$ in the surface layer of the model. Hence, the ultimate reason for the difference among the experiments is that biological production is at its maximum in the ocean interior (at ca. $60 \mathrm{~m}$ ) in summer, and at the surface in winter, whereas 
a.

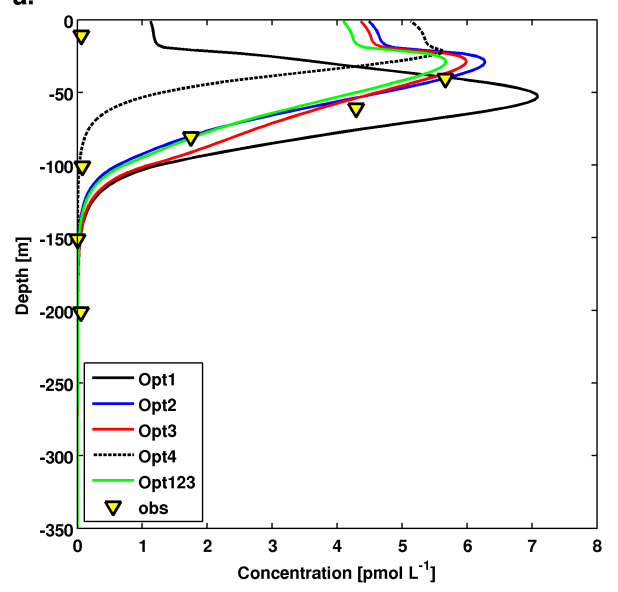

b.

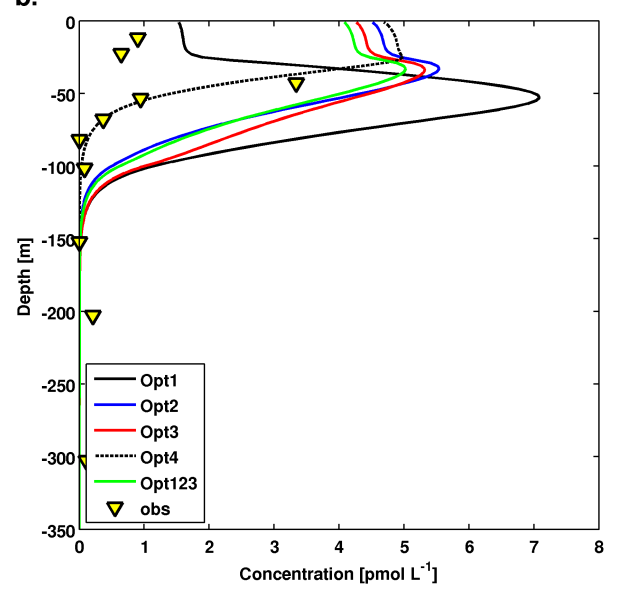

Fig. 4. Methyl iodide concentration profiles $\left[\mathrm{pmolL}^{-1}\right.$ ] from stations CVOO and St. 308 in the Cape Verde region. Observed data were collected during Poseidon cruise P399/2 in 2010. For the CVOO station only data from the upper $350 \mathrm{~m}$ of the water column are shown.

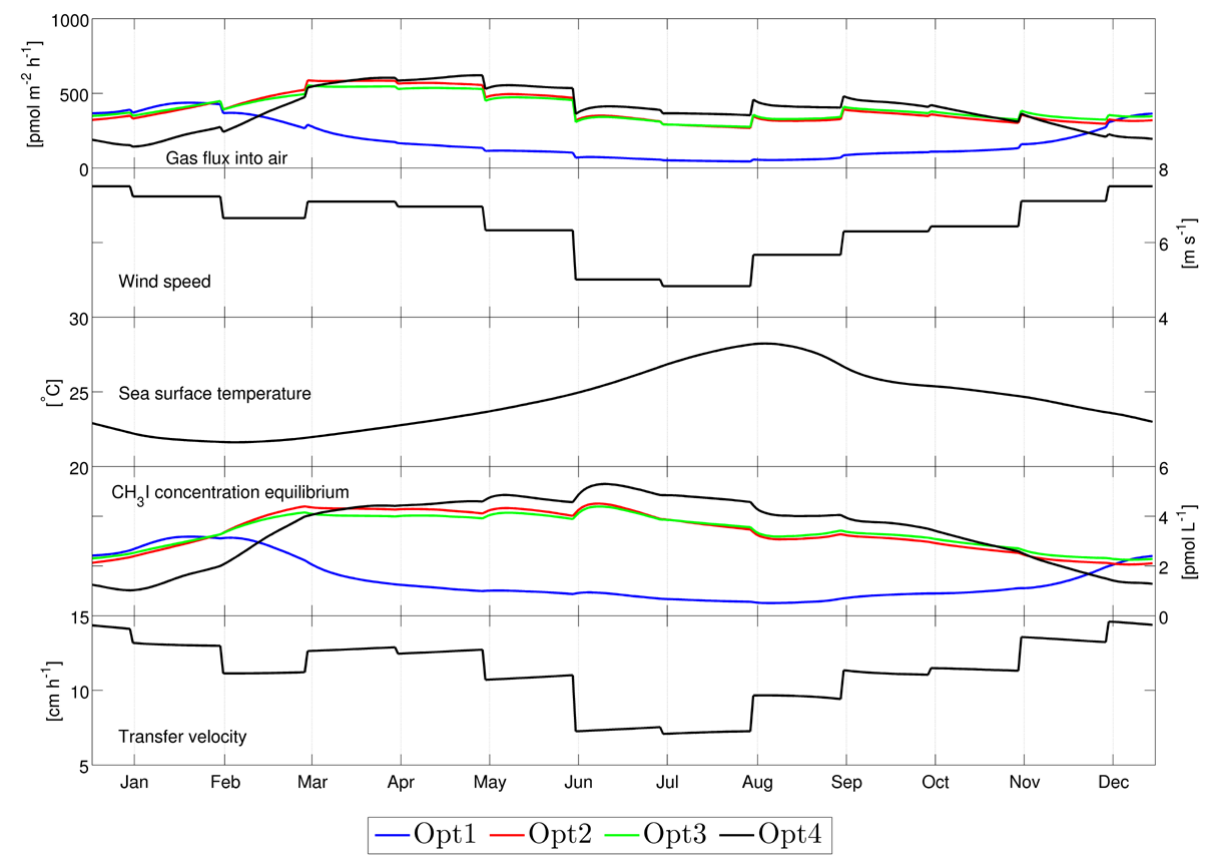

Fig. 5. Methyl iodide sea-air flux $\left[\mathrm{pmolm}^{-2} \mathrm{~h}^{-1}\right]$, wind speed $\left[\mathrm{ms} \mathrm{s}^{-1}\right]$, sea surface temperature $\left[{ }^{\circ} \mathrm{C}\right], \mathrm{CH}_{3} \mathrm{I}$ water and air concentration equilibrium $c_{\mathrm{W}}-\frac{c_{\mathrm{a}}}{H},\left[\mathrm{pmolL} \mathrm{L}^{-1}\right]$, and gas transfer velocity $\left[\mathrm{cmh}^{-1}\right]$.

photochemical production is highest in the sun-lit surface layers during spring and summer. When production is limited to photochemical production, the seasonal cycle of the gas exchange is less pronounced (Fig. 5). This is because the temporal evolution of production is controlled by radiation, and hence strongest in summer, when low wind speeds lead to a lower transfer velocity. Other than by production and associated surface concentrations, the evolution of the fluxes is determined by wind speed and sea surface temperature. The low temporal resolution of wind speed (monthly means) via the transfer velocity shapes the month-to-month variation of the fluxes, which is characterized by an abrupt (non-smooth) transition from one month to the other (Fig. 5). Within individual months, temperature, which determines the solubility, and surface concentration control the deviation from equilibrium between atmosphere and ocean, and hence the evolution of sea-air fluxes. 


\section{Discussion}

The profiles of temperature, salinity, phytoplankton, and nutrients at CVOO and St. 308 during P399/2 are similar to observations in Meteorcruise M55 (Wallace and Bange, 2004) and the World Ocean Atlas (Conkright et al., 2002); hence the observed profiles at these stations do not represent unusual environmental conditions. Therefore our results can be transferred to areas of the eastern tropical Atlantic where advection plays a minor role.

\section{1 $\mathrm{CH}_{3} \mathrm{I}$ production by phytoplankton}

Modelling $\mathrm{CH}_{3} \mathrm{I}$ distributions at $\mathrm{CVOO}$ and St. 308 using biological production rates derived from laboratory experiments (E1, E2) was not successful. The production rate as suggested by Moore et al. (1996) appears to be too low to reproduce observed $\mathrm{CH}_{3} \mathrm{I}$ concentrations, whereas the production rate suggested by Smythe-Wright et al. (2006) seems to be too high. This does not imply that direct biological production of methyl iodide is unlikely. The parameter optimization for the cases where only biological production was included (Opt1) resulted in lowest RMSD values for a production rate in the order of magnitude of $10^{-6} \mathrm{mmolCH}_{3} \mathrm{I}(\mathrm{kmolP})^{-1}$, and the overall shape of the vertical profiles was best reproduced. Hughes et al. (2011) suggested that the large discrepancies between the production rates from laboratory studies result from the different health conditions of the phytoplankton cells. As in nature the phytoplankton population can consist of mixed healthy and stressed cells (Agusti, 2004), it is not unrealistic to expect a bulk $\mathrm{CH}_{3} \mathrm{I}$ production rate in between the two discussed. Here, we tested if enhanced production under oligotrophic conditions would result in a better representation of $\mathrm{CH}_{3} \mathrm{I}$ profiles close to Cape Verde. But, even after optimization of the parameter setup this experiment did not reproduce observed concentrations satisfactorily.

The preliminary analysis of pigment measurements in the cruise report (Bange, 2011) indicates a high abundance of diatoms during P399/2, but also suggests the presence of Prochlorococcus, the plankton species that was shown to enhance $\mathrm{CH}_{3} \mathrm{I}$ release during stress. Unfortunately, nothing is known about the cell physiological state of phytoplankton during the cruise. Hence, either nutrient scarcity is not a good proxy for stressed phytoplankton cells that produce more $\mathrm{CH}_{3} \mathrm{I}$ than healthy ones and the chosen parameterisation of that factor is inadequate, or enhanced production by stressed cells is not relevant at these two stations. Since for both stations the same physical setup of GOTM is used, particularities of the two stations are not reflected by the model, e.g. if enhanced production by stressed picocyanobacteria would be more likely for St. 308 than for CVOO. In addition, the ecosystem model used is rather simple, and biological production of methyl iodide is described to be coupled to primary production of the bulk phytoplankton. Since Prochloro- coccus is assumed to be the main producer of methyl iodide an explicit description of this phytoplankton group in the model might improve the overall representation of phytoplankton biomass and methyl iodide concentration. Yet, different ecotypes of Prochlorococcus exist (e.g. Johnson et al., 2006) and we cannot exclude that depth-dependent niche separation might also affect methyl iodide production and vertical distribution patterns of $\mathrm{CH}_{3} \mathrm{I}$ concentrations. However, since our simulated subsurface $\mathrm{CH}_{3} \mathrm{I}$ concentrations are in the same order of magnitude compared to observations (see Appendix A), we refrain from adding more complexity to the model system.

Another aspect in the evaluation of the simulated biologically produced $\mathrm{CH}_{3} \mathrm{I}$ profile is the vertical distribution. In the experiments that include biological production of $\mathrm{CH}_{3} \mathrm{I}$ using a constant production ratio, the depth of the maximum of primary production determines the depth of the maximum of $\mathrm{CH}_{3} \mathrm{I}$ concentrations. As presented in Appendix A, the modelled phytoplankton concentration was compared to observed chlorophyll $a$ data. Both show a subsurface maximum and are in the same order of magnitude. The exact location of the biomass maximum during the cruise, however, cannot be unambiguously assessed as the phytoplankton concentration in model units has to be diagnosed from an empirically derived depth-dependent relationship between chlorophyll and carbon. There is no doubt that the $\mathrm{C}: \mathrm{Chl}$ ratio varies with depth (with higher values at the surface than subsurface), but there is no mechanistic understanding about the co-variation of carbon and chlorophyll with depth. Therefore, a match or mismatch of the exact location of the $\mathrm{CH}_{3} \mathrm{I}$ maximum is not a good indicator for the model performance here.

\subsection{Photochemical production of $\mathrm{CH}_{3} \mathrm{I}$}

The experiments that are dominated by photochemical production are very successful in representing the subsurface $\mathrm{CH}_{3} \mathrm{I}$ concentrations (below the maximum), and only the surface value is not represented by the model (Fig. 4). In particular, the concentrations at $\mathrm{CVOO}$ are well reflected by the model. But, simulated methyl iodide concentrations were found to be sensitive to the absorption properties of light. A subsurface maximum is only simulated during times of a shallow mixed layer and when using light that is penetrating deep enough to allow for production below the mixed layer. UV light gets absorbed readily in the water column, whereas other wavelengths show significant intensities down to approximately $100 \mathrm{~m}$ (e.g. PAR). Thus far, the photochemical production pathway has not yet been fully understood. Wang et al. (2009) found positive correlations of $\mathrm{CH}_{3} \mathrm{I}$ concentrations with both PAR and UV light at $325 \mathrm{~nm}$; Moore and Zafiriou (1994) detected methyl iodide production in laboratory studies when using light with a spectral distribution close to sunlight over the wavelength $280-1100 \mathrm{~nm}$. Richter and Wallace (2004) tested $\mathrm{CH}_{3} \mathrm{I}$ production under different light conditions to study the qualitative effect of UV light 
on production. They did not discover any significant differences in $\mathrm{CH}_{3} \mathrm{I}$ production between the experiment with the full spectrum of light compared to the ones with reduced UV light. Photochemistry potentially impacts this production pathway twofold: on the one hand, the iodine atoms may originate from reaction of iodide with photochemically produced oxidants or photolysis of organic iodides, and on the other hand, the methyl radicals may originate from photolysis of humic material (Moore and Zafiriou, 1994). As photochemical production of e.g. $\mathrm{OH}^{-}$from CDOM is more efficient for UV light (e.g. Loiselle et al., 2012) one could speculate about more significant differences in $\mathrm{CH}_{3} \mathrm{I}$ production if the impact of light would be studied for various water depths. But for now, there is no experimental evidence that $\mathrm{CH}_{3} \mathrm{I}$ production occurs preferentially under UV light. The sensitivity of the model results to the absorption characteristics suggest that further studies on the wavelength dependency of $\mathrm{CH}_{3} \mathrm{I}$ production would be valuable.

\subsection{Mixed biological and photochemical $\mathrm{CH}_{3} \mathrm{I}$ sources}

Similar to the experiments with photochemical $\mathrm{CH}_{3} \mathrm{I}$ production, the mixed-source experiment, Opt123, shows highest discrepancies between modelled and observed concentrations at the surface. As the optimization is set up to find the minimum RMSD for both maximum and mean along the profile, the discrepancy in the surface value is not weighted strongly enough to force the mixed-source parameter optimization towards a biological production. Hence, one cannot conclude from the mere fact that the optimization suppressed biological production that photochemical production is the main source process of $\mathrm{CH}_{3} \mathrm{I}$ here. As in oligotrophic waters, deep phytoplankton maxima regularly occur higher biologically mediated methyl iodide production at depth can hence not be excluded. Smythe-Wright et al. (2006) detected enhanced subsurface $\mathrm{CH}_{3} \mathrm{I}$ concentrations where Prochlorococcus were largely abundant. They found much higher $\mathrm{CH}_{3} \mathrm{I}$ concentrations during their cruise at Cape Verde compared to P399/2, although both cruises were conducted in the same season. In addition, Smythe-Wright et al. (2006) found elevated surface concentrations as well as associated high atmospheric levels. Thus, the variability might not be insignificant.

\subsection{Gas exchange with the atmosphere}

Gas exchange with the atmosphere depends on the deviations from equilibrium of marine and atmospheric methyl iodide concentrations, as well as on the wind-speed dependent transfer velocity. Saturation anomalies can be evaluated since they are derived frequently during ship cruises when atmospheric and oceanic $\mathrm{CH}_{3} \mathrm{I}$ concentrations are measured simultaneously. Smythe-Wright et al. (2006) diagnose concentration anomalies of $40 \mathrm{pmolL}^{-1}$ in May from data collected in the eastern Atlantic close to $20^{\circ} \mathrm{N}$, resulting from very high $\mathrm{CH}_{3} \mathrm{I}$ concentrations in water. Concentrations measured during P399/2 and our simulations show much lower values. The concentration anomaly between water and air of approximately $5-10 \mathrm{pmolL}^{-1}$ modelled here is closer to what was estimated by Happell and Wallace (1996), Richter and Wallace (2004), or Chuck et al. (2005). Clearly, as model results were optimized for certain sea water concentrations, a direct comparison to other measured data is only possible when these coincide with the ones at P399/2. Chuck et al. (2005), for example, measured surface water concentration of approximately $5 \mathrm{pmolL}^{-1}$ off Africa at $15-20^{\circ} \mathrm{N}$, which is much higher than concentrations measured during P399/2. Thus, the variability of methyl iodide concentrations both in surface ocean and lower atmosphere concentrations is not insignificant.

Generally, the strength of modelled sea-air fluxes does not vary much among the experiments, but its seasonal cycle does. Even though the large differences in intensity of gas exchange for experiments that include different dominating source processes seems to be an inherent feature of production, the sea-air flux cannot be used to argue for a certain source type. This is because in the model sea-air exchange is only diagnosed from a constant atmospheric concentration. Using a model that includes the full cycling of $\mathrm{CH}_{3} \mathrm{I}$ in both atmosphere and ocean would account for the variability of atmospheric $\mathrm{CH}_{3} \mathrm{I}$ concentrations. But, the simulated seasonal cycle is not expected to change much when a model of atmospheric $\mathrm{CH}_{3} \mathrm{I}$ cycling is added. This is because the saturation anomaly is mostly influenced by the oceanic values, due to the strong oversaturation of the ocean. Strong oversaturation has been found previously for both early summer month (May/June: O'Brien et al., 2009; Fuhlbrügge et al., 2012 and late fall (October/November: Butler et al., 2007). Furthermore, the measured mixing ratios both in May/June and October/November over the open ocean close to Cape Verde were in the range of 1-2 ppt (Butler et al., 2007; O'Brien et al., 2009; Fuhlbrügge et al., 2012). Hence, the expected seasonal variability of atmospheric concentrations will be much lower than the one of sea water concentrations (which show a factor of 6 between low summer and high winter values in the simulations). Here, monthly means were used to force the model at the atmospheric boundary ( $2 \mathrm{~m}$ temperature, wind speed, etc.). Usage of e.g. daily mean data would introduce higher temporal variability to the fluxes, but would not change the seasonal cycle, the magnitude of the mean fluxes or generate additional differences amongst the experiments.

High concentrations of methyl iodide in the surface ocean and lower atmosphere that have been observed occasionally in this region might also be the result of horizontal advection. Since we use a one-dimensional water column model, this non-local source cannot be represented by our model system. As a next step, we therefore aim to couple the biogeochemical module to a three-dimensional global ocean circulation model to account for horizontal and vertical advection. 


\section{Conclusions}

The coupled biogeochemical-water column model that includes a methyl iodide compartment is able to reproduce observed subsurface maxima of $\mathrm{CH}_{3} \mathrm{I}$ concentrations. However, our model results are not unequivocal. Subsurface maxima can occur due to direct biological and photochemical production. But, for the photochemical production pathway subsurface maxima strongly depend on the chosen light properties. Subsurface maxima can occur only if significant production occurs also below the mixed layer. This is not the case when only UV light is considered in the production mechanism. However, the gradient, i.e. the difference between surface and subsuface methyl iodide concentration, is best reproduced if direct biological production is taken into account. Although enhanced methyl iodide production is observed under stress conditions of picocyanobacteria, the parameterization of this process has not led to a model improvement at this particular site.

Overall, we conclude that the rates obtained from the laboratory experiments from Moore et al. (1996) are too low to explain the $\mathrm{CH}_{3} \mathrm{I}$ concentration in the tropical northeast Atlantic. In contrast, the $\mathrm{CH}_{3} \mathrm{I}$ production rates in this region cannot be as high as proposed by Smythe-Wright et al. (2006) at least not over longer times. The comparison of horizontal distribution patterns between simulated and observed $\mathrm{CH}_{3} \mathrm{I}$ concentrations may provide further insights into the source of $\mathrm{CH}_{3} \mathrm{I}$.

\section{Appendix A}

\section{Evaluation of the physical and biological state of model}

For all simulations the model was restored towards salinity and temperature profiles from the tropical northeast Atlantic (see Sect. 2.4). But, this does not guarantee that the simulated ocean state is representing conditions during the Poseidon cruise (P399/2), in particular as those might be different for the two stations (CVOO, St. 308). Therefore, simulated temperature, salinity, and phytoplankton profiles in April and June are compared to observations taken during P399/2. At the CVOO station and at St. 308 temperature and salinity profiles are similar to the observed ones (Fig. A1a, b). The greatest mismatch occurs in the surface layer, where no restoring takes place. There, salinity and temperature are strongly influenced by vertical exchange via turbulence, surface fluxes (momentum, heat, radiation), which are a function of the forcing used. The forcing taken from climatological mean data cannot fully represent local conditions during the cruise. But, the use of other data sets and forcing fields (e.g. 2010 data of the NCEP global ocean data assimilation system (GODAS): http://www.esrl.noaa.gov/psd/ data/gridded/data.godas.html, Behringer and Xue, 2004) has not improved the representation of observed profiles. Us-
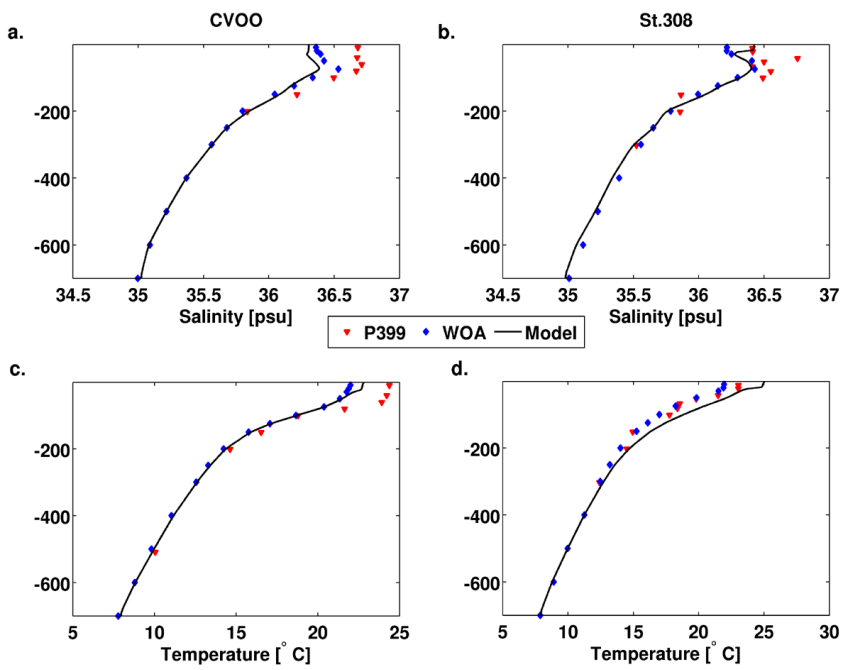

Fig. A1. Salinity $[\mathrm{psu}](\mathbf{a}, \mathbf{b})$ and temperature $\left[{ }^{\circ} \mathrm{C}\right](\mathbf{c}, \mathbf{d})$ profiles in April (a, c) and June (b, d), model predictions (solid lines) and observations (red markers P399/2 cruise data, blue markers WOA data).
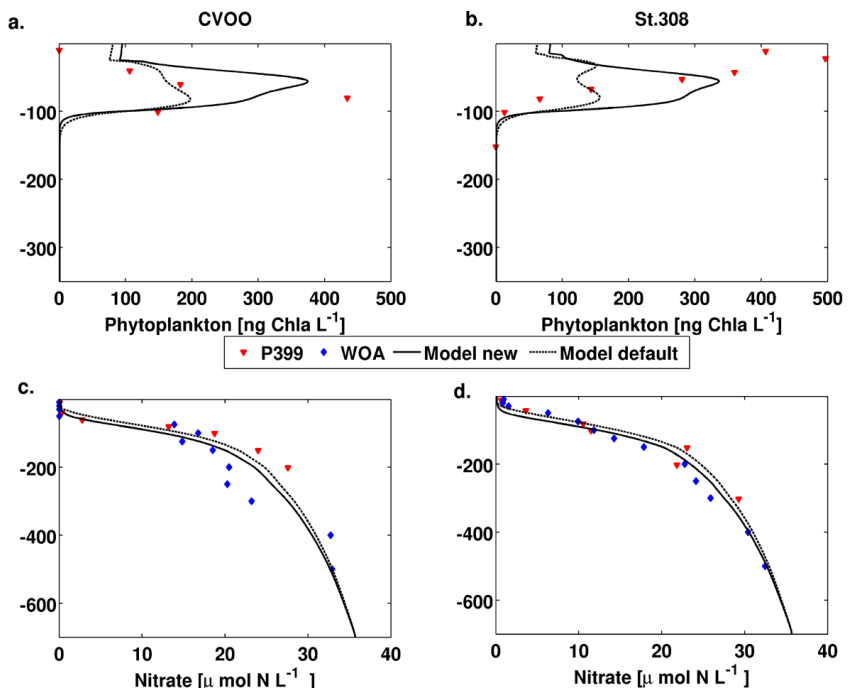

Fig. A2. Phytoplankton (a, b) and nutrient $(\mathbf{c}, \mathbf{d})$ concentrations in April (a, c) and June (b, d) [ng Chl $\left.a \mathrm{~L}^{-1}\right]$ - model-predicted (black solid lines new and dashed lines default parameter setup) and observed (red markers) profiles. Observations were taken from the Poseidon cruise P399/2 in 2010. Simulated phytoplankton concentrations have been converted to chlorophyll using a vertically dependent C : Chl ratio (e.g. Hense and Beckmann, 2008) and the Redfield ratio for conversion from carbon to phosphorus.

age of the measured profiles would improve model results, but would introduce inconsistencies as in situ data would be treated as monthly means, and these data would have to be combined with other data as only observations for a limited time period in spring and summer are available. Modelled 

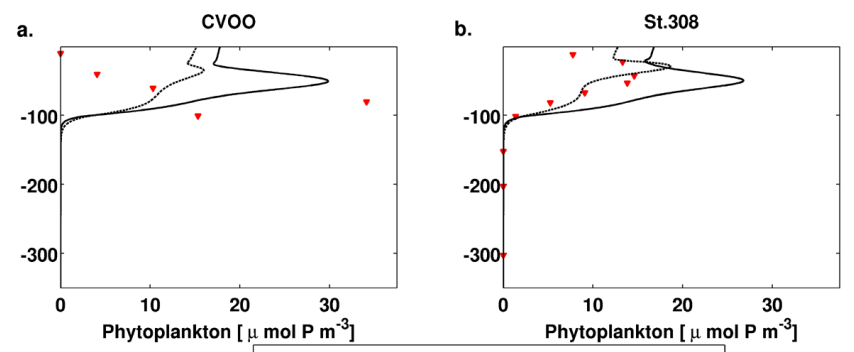

- P399 - WOA -
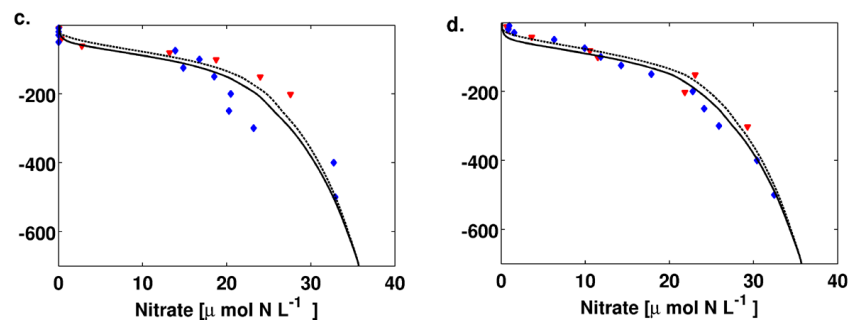

Fig. A3. Phytoplankton (a, b) and nutrient $(\mathbf{c}, \mathbf{d})$ concentrations in April $(\mathbf{a}, \mathbf{c})$ and June $(\mathbf{b}, \mathbf{d})\left[\mu \mathrm{molPm} \mathrm{Pm}^{-3}\right]$ - model-predicted (black solid lines new and dashed lines default parameter setup) and observed (red markers) profiles. Observations were taken from the Poseidon cruise P399/2 in 2010. Phytoplankton concentrations have been derived from chlorophyll, using a vertically dependent $\mathrm{C}: \mathrm{Chl}$ ratio (e.g. Hense and Beckmann, 2008) and the Redfield ratio for conversion from carbon to nitrogen.

nutrient profiles (Fig. A2c, d) at CVOO and St. 308 closely match observed ones.

Modelled and observed phytoplankton biomass profiles (Fig. A3a, b) show similarities, but also significant differences. Similar to observations, the model predicts a subsurface phytoplankton maximum, but location and extent differ among the two stations and also compared to model results. Phytoplankton biomass is calculated from a depthdependent $\mathrm{C}: \mathrm{Chl}$ ratio. The ratio is derived from an empirical parameterization, which introduces uncertainties to the observations. Number (for model results), location, and strengths of subsurface maxima change when using biomass instead of chlorophyll as a measure for phytoplankton concentrations (compare Figs. A2 and A3). A direct comparison of model results to measured phytoplankton pigments on the other hand is not possible as chlorophyll is not a prognostic variable of the model. Nevertheless, modelled and observation-based phytoplankton concentrations are in the same order of magnitude and show a similar vertical profile. Unfortunately, there is no information on primary production available for the cruise P399/2. However, previous measurements in this region show values in the range between 0.3 to $2.6 \mathrm{~g} \mathrm{C} \mathrm{d}^{-1} \mathrm{~m}^{-2}$ (summer and fall for the oligotrophic/mesotrophic region; see Morel et al., 1996). Vertically integrated $(0-100 \mathrm{~m})$ daily primary production derived from our model ranges between 0.7 and $1.4 \mathrm{~g} \mathrm{C} \mathrm{d}^{-1} \mathrm{~m}^{-2}$. Thus, our model matches previously observed values well.
Acknowledgements. The authors are grateful to Ilka Peeken (Alfred Wegner Institute Bremerhaven) and Hermann Bange (GEOMAR Helmholtz Centre for Ocean Research Kiel) for providing phytoplankton pigment, salinity, and temperature data from the Poseidon cruise P399/2 and to Birgit Quack (GEOMAR Helmholtz Centre for Ocean Research Kiel) for valuable discussions. The constructive comments by $\mathrm{C}$. Völker and an anonymous reviewer are gratefully acknowledged. The study was funded by the German BMBF project SOPRAN (Surface Ocean Processes in the Anthropocene) SOPRAN I 03F0462E, SOPRAN II 03F0611E; IH is financed through the Cluster of Excellence "CliSAP" (EXC177), University of Hamburg, funded through the German Science Foundation (DFG).

Edited by: X. Wang

\section{References}

Agusti, S.: Viability and niche segregation of Prochlorococcus and Synechococcus cells across the Central Atlantic Ocean, Aquat. Microb. Ecol., 36, 53-59, 2004.

Bange, H.: FS Poseidon Fahrtbericht/Cruise Report P399 - 2\&3 : Eastern tropical North Atlantic; P399-2: 31.04.2010-17.06.2010 Las Palmas - Las Palmas (Canary Islands), P399-3: 18.24.06.2010 Las Palmas (Canary Islands) - Vigo (Spain); DRIVE (Diurnal and RegIonal Variability of Halogen Emmissions), SOPRAN, Cruise Report 10.3289/ifm-geomar_rep_48_2011, IfMGeomar Kiel, Kiel, http://oceanrep.geomar.de/12032/, 2011.

Behringer, D. and Xue, Y.: Evaluation of the Global Ocean Data Assimilation System at NCEP: The Pacific Ocean. Preprints, Eighth Symp. on Integrated Observing and Assimilation Systems for Atmosphere, Oceans, and Land Surface, Seattle, WA, Amer. Meteor. Soc., available at: http://www.cpc.ncep.noaa.gov/products/ people/yxue/pub/13.pdf, 2004.

Bell, N., Hsu, L., Jacob, D., Schultz, M., Blake, D., Butler, J., King, D., Lobert, J., and Maier-Reimer, E.: Methyl iodide: Atmospheric budget and use as a tracer of marine convection in global models, J. Geophys. Res., 107, 8-1-8-12, 2002.

Brownell, D., Moore, R., and Cullen, J.: Production of methyl halides by Prochlorococcus and Synechococcus, Glob. Biogeochem. Cy., 24, GB2002, doi:10.1029/2009GB003671, 2010.

Butler, J.H.and King, D., Lobert, J.M.and Montzka, S., YvonLewis, S., Hall, B., Warwick, N., Mondell, D., Aydin, M., and Elkins, J.: Oceanic distributions and emissions of shortlived halocarbons, Global Biogeochem. Cy., 21, GB1023, doi:doi:10.1029/2006GB002732, 2007.

Carlson, C.: Biogeochemistry of marine dissolved organic matter, chap. Production and removal processes, 91-152, Academic Press, An Elsevier Science Imprint, 2002.

Carpenter, L.: Iodine in the Marine Boundary Layer, Chem. Rev., 103, 4953-4962, 2003.

Carpenter, L. and Liss, P.: On temperate sources of bromoform and other reactive organic bromine gases, J. Geophys. Res., 105, 20539-20547, 2000.

Chameides, W. and Davis, D.: Iodine: Its Possible Role in Tropospheric Photochemistry, J. Geophys. Res., 85, 7383-7398, 1980.

Chuck, A., Turner, S., and Liss, P.: Oceanic distributions and air-sea fluxes of biogenic halocarbons in the open ocean, J. Geophys. Res., 110, 1-12, 2005. 
Conkright, M. E., Locarnini, R. A., Garcia, H. E., O’Brien, T. D., Boyer, T. P., Stephens, C., and Antonov, J. I.: World Ocean Atlas 2001: Objective Analyses, Data Statistics, and Figures, CDROM Documentation, Tech. rep., National Oceanographic Data Center, Silver Spring, MD, USA, 2002.

Dittmar, W.: Part I. Report on researches into the composition of ocean-water, collected by H. M. S. Challenger, during the years 1873-1876, Physics and Chemistry, 1, 1-247, 1884.

Elliott, S. and Rowland, F.: Nucleophilic substitution rates and solubilities for methyl halides in seawater, Geophys. Res. Lett., 20, 1043-1046, 1993.

Elliott, S. and Rowland, F.: Methyl halide hydrolysis rates in natural waters, J. Atmos. Chem., 20, 229-236, 1995.

Fuhlbrügge, S., Krüger, K., Quack, B., Atlas, E., Hepach, H., and Ziska, F.: Impact of the marine atmospheric boundary layer on VSLS abundances in the eastern tropical and subtropical North Atlantic Ocean, Atmos. Chem. Phys. Discuss., 12, 31205-31245, doi:10.5194/acpd-12-31205-2012, 2012.

Giese, B., Laturnus, F., Adams, F. C., and Wiencke, C.: Release of Volatile Iodinated $\mathrm{C}_{1}-\mathrm{C}_{4}$ Hydrocarbons by Marine Macroalgae from Various Climate Zones, Environ. Sci. Technol., 33, 24322439, doi:10.1021/es980731n, 1999.

Happell, J. and Wallace, D.: Methyl iodide in the Greenland/Norwegian Seas and the tropical Atlantic Ocean: Evidence for photochemical production, Geophys. Res. Lett., 23, 21052108, 1996.

Hense, I. and Beckmann, A.: Revisiting subsurface chlorophyll and phytoplankton distributions, Deep-Sea Res. Pt. I, 55, 1193-1199, 2008.

Hense, I. and Quack, B.: Modelling the vertical distribution of bromoform in the upper water column of the tropical Atlantic Ocean, Biogeosciences, 6, 535-544, doi:10.5194/bg-6-535-2009, 2009.

Hughes, C., Franklin, D., and Malin, G.: Iodomethane production by two important marine cyanobacteria: Prochlorococcus marinus (CCMP 2389) and Synechococcus sp. (CCMP 2370), Mar. Chem., 125, 19-25, 2011.

Ilyina, T., Six, K. D., Segschneider, J., Maier-Reimer, E., Li, H., and Núñez-Riboni, I.: The global ocean biogeochemistry model HAMOCC: Model architecture and performance as component of the MPI-earth system model in different CMIP5 experimental realizations, JAMES, accepted, doi:10.1002/jame.20017, 2013.

Johnson, Z. I., Zinser, E., Coe, A., McNulty, N., Woodward, E., and Chisholm, S.: Niche partitioning among Prochlorococcus ecotypes along oceanscale environmental gradients, Science, 311, 1737-1740, 2006.

Loiselle, S., Vione, D., Minero, C., Maurino, V., Tognazzi, A., Dattilo, A. M., Rossi, C., and Bracchini, L.: Chemical and optical phototransformation of dissolved organic matter, Water Res., 46, 3197-3207, doi:10.1016/j.watres.2012.02.047, 2012.

Lovelock, J., Maggs, R., and Wade, R.: Halogenated hydrocarbons in and over the Atlantic [8], Nature, 241, 194-196, 1973.

Manley, S. and Dastoor, M.: Methyl iodide $\left(\mathrm{CH}_{3} \mathrm{I}\right)$ production by kelp and associated microbes, Mar. Biol., 98, 477-482, 1988.

Manley, S. and De La Cuesta, J.: Methyl iodide production from marine phytoplankton cultures, Limnol. Oceanogr., 42, 142-147, 1997.

Moore, R.: Methyl halide production and loss rates in sea water from field incubation experiments, Mar. Chem., 101, 213-219, 2006.
Moore, R. and Groszko, W.: Methyl iodide distribution in the ocean and fluxes to the atmosphere, J. Geophys. Res., 104, 1116311171, doi:10.1029/1998JC900073, 1999.

Moore, R. and Tokarczyk, R.: Volatile biogenic halocarbons in the northwest Atlantic, Global Biogeochem. Cy., 7, 195-210, 1993.

Moore, R. and Zafiriou, O.: Photochemical production of methyl iodide in seawater, J. Geophys. Res., 99, 16415-16420, 1994.

Moore, R., Geen, C., and Tait, V.: Determination of Henry's law constants for a suite of naturally occurring halogenated methanes in seawater, Chemosphere, 30, 1183-1191, 1995.

Moore, R., Webb, M., Tokarczyk, R., and Wever, R.: Bromoperoxidase and iodoperoxidase enzymes and production of halogenated methanes in marine diatom cultures, J. Geophys. Res., 101, 20899-20908, 1996.

Morel, A., Antoine, D., Babin, M., and Dandonneau, Y.: Measured and modeled primary production in the northeast Atlantic (EUMELI JGOFS program): the impact of natural variations in photosynthetic parameters on model predictive skill,, Deep-Sea Res. Pt. I, 43, 1273-1304, 1996.

Nightingale, P., Malin, G., and Liss, P.: Production of chloroform and other low-molecular-weight halocarbons by some species of macroalgae, Limnol. Oceanogr., 40, 680-689, 1995.

Nightingale, P. D., Malin, G., Law, C., Watson, A., Liss, P., Liddicoat, M., Boutin, J., and Upstill-Goddard, R.: In situ evaluation of air-sea gas exchange parameterizations using novel conservative and volatile tracers, Global Biogeochem. Cy., 14, 373-387, 2000.

O’Brien, L. M., Harris, N. R. P., Robinson, A. D., Gostlow, B., Warwick, N., Yang, X., and Pyle, J. A.: Bromocarbons in the tropical marine boundary layer at the Cape Verde Observatory - measurements and modelling, Atmos. Chem. Phys., 9, 9083-9099, doi:10.5194/acp-9-9083-2009, 2009.

Partensky, F., Hess, W., and Vaulot, D.: Prochlorococcus, a marine photosynthetic prokaryote of global significance, Microbiol. Mol. Biol. R., 63, 106-127, 1999.

Rattigan, O., Shallcross, D., and Cox, R.: UV absorption crosssections and atmospheric photolysis rates of $\mathrm{CF}_{3} \mathrm{I}, \mathrm{CH}_{3} \mathrm{I}, \mathrm{C}_{2} \mathrm{H}_{5} \mathrm{I}$ and $\mathrm{CH}_{2} \mathrm{ICl}$ J. Chem. Soc.-Faraday T., 93, 2839-2846, 1997.

Richter, U. and Wallace, D.: Production of methyl iodide in the tropical Atlantic Ocean, Geophys. Res. Lett., 31, 1-4, 2004.

Six, K. and Maier-Reimer, E.: Effects of plankton dynamics on seasonal carbon fluxes in an ocean general circulation model, Global Biogeochem. Cy., 10, 559-583, 1996.

Smythe-Wright, D., Boswell, S., Breithaupt, P., Davidson, R., Dimmer, C., and Eiras Diaz, L.: Methyl iodide production in the ocean: Implications for climate change, Global Biogeochem. Cy., 20, GB3003, doi:10.1029/2005GB002642, 2006.

Solomon, S., Garcia, R., and Ravishankara, A.: On the role of iodine in ozone depletion, J. Geophys. Res., 99, 20491-20499, 1994.

Sulzberger, B. and Durisch-Kaiser, E.: Chemical characterization of dissolved organic matter (DOM): A prererquisite for understanding UV-induced changes of DOM absorption properties and bioavailabilty, Aquat. Sci., 71, 104-126, 2009.

Umlauf, L., Burchard, H., and Bolding, K.: GOTM -scientific documentation: version 3.2, Mar. Sci. Rep., 63, 1-346, 2005.

Uppala, S. M., Kållberg, P. W., Simmons, A. J., Andrae, U., Bechtold, V. D. C., Fiorino, M., Gibson, J. K., Haseler, J., Hernandez, A., Kelly, G. A., Li, X., Onogi, K., Saarinen, S., Sokka, N., Allan, R. P., Andersson, E., Arpe, K., Balmaseda, M. A., Beljaars, 
A. C. M., Berg, L. V. D., Bidlot, J., Bormann, N., Caires, S., Chevallier, F., Dethof, A., Dragosavac, M., Fisher, M., Fuentes, M., Hagemann, S., Hólm, E., Hoskins, B. J., Isaksen, L., Janssen, P. A. E. M., Jenne, R., Mcnally, A. P., Mahfouf, J.-F., Morcrette, J.-J., Rayner, N. A., Saunders, R. W., Simon, P., Sterl, A., Trenberth, K. E., Untch, A., Vasiljevic, D., Viterbo, P., and Woollen, J.: The ERA-40 re-analysis, Q. J. Roy. Meteorol. Soc., 131, 2961-3012, doi:10.1256/qj.04.176, 2005.

Vogt, R., Sander, R., Von Glasow, R., and Crutzen, P.: Iodine chemistry and its role in halogen activation and ozone loss in the marine boundary layer: A model study, J. Atmos. Chem., 32, 375395, 1999.

Wallace, D. R. and Bange, H.: Introduction to special section: Results of the Meteor 55: Tropical SOLAS Expedition, Geophys. Res. Lett., 31, L23S01, doi:10.1029/2004GL021014, 2004.
Wang, L., Moore, R., and Cullen, J.: Methyl iodide in the NW Atlantic: Spatial and seasonal variation, J. Geophys. Res., 114, C07007, doi:10.1029/2007JC004626, 2009.

Weber, L., Völker, C., Oschlies, A., and Burchard, H.: Iron profiles and speciation of the upper water column at the Bermuda Atlantic Time-series Study site: a model based sensitivity study, Biogeosciences, 4, 689-706, doi:10.5194/bg-4-689-2007, 2007.

Wetzel, P., Maier-Reimer, E., Botzet, M., Jungclaus, J., Keenlyside, N., and Latif, M.: Effects of ocean biology on the penetrative radiation in a coupled climate model, J. Climate, 19, 3973-3987, 2006. 